ARTICLE

DOI: $10.1057 / s 41599-018-0170-0$

\title{
Trumpism: a disfigured Americanism
}

Mimi Yang ${ }^{1}$

\begin{abstract}
The current cultural turmoil in the U.S. is much associated with Trumpism. This article asserts that Trumpism has its ideological root in nativism, a cultural tradition perpetuated by John Higham. To point out the disfigured Americanism in Trumpism, this paper theorizes the vertical America and the horizontal America, and dissects their complex interplay and symbiosis in an evolving American culture. The vertical Americanism sets hierarchies to secure power and control as well as maintain racial and cultural "purity;" the horizontal Americanism, epitomized by Martin Luther King and Barack Obama, equalizes and connects across races, creeds, and social classes. The color line (in Dubois' term) thus becomes a converging and diverging boundary between the two Americas; it harbors and delineates Trumpism. It is argued that disfigurement of Americanism comes from a disruptive and destructive interplay of the vertical and the horizontal in Trump's America.
\end{abstract}

\footnotetext{
${ }^{1}$ Carthage College, Modern Languages, Kenosha, WI, USA. Correspondence and requests for materials should be addressed to M.Y. (email: myang@carthage.edu)
} 


\section{Introduction}

This land is your land, this land is my land From the California to the New York island From the Redwood Forest, to the gulf stream waters This land was made for you and me As I went walking that ribbon of highway I saw above me that endless skyway And saw below me that golden valley This land was made for you and me

\section{$\cdots \cdots$}

W hen the American "Troubadour" Woody Guthrie composed the lyrics of "This Land Is Your Land" in 1940 , he had just completed one of his major migrations, the trans-continental journey from California to New York, in search of job and shelter. He protested the Dust Bowl experiences in his adulthood, imagined an idyllic America where everyone has a place, and sought social justice in an environment characteristic of inequality, discrimination, and exclusion. Guthrie sang from his soul a land that flattens social hierarchies and erases divides between us and them. It is an ideal and dream land for a horizontal America.

In an unimpeded and sweeping horizontality, "from California to New York island," everywhere is replete with bright colors and fresh air, celebrating this land and singing the symphony of American voices. Guthrie's song sings of an equalizing Americanism. Clearly, he envisions a paradisiacal land where the most impossible dream can come true. That is the American Dream, meant for all of us, regardless of race, creed, color or gender. The horizontal perspective is also a precursor of Martin Luther King's dream that one day we all cross racial barriers and level cultural hierarchies and be judged by the content of our character not the color of our skin, and that a racially harmonious and interconnected society define America. However, between dream and reality there is always a distance. It has been the vertical America building walls and blocking the views. In a divisive and combative time like the Trump era that we are presently living, bigotry, hate, and intolerance distance Guthrie's American Dream even further from Trump's American reality. In fact, we find ourselves catapulted into an abyss that separates the two Americas: one envisioned by Guthrie and one enacted by Trump. While both claiming American values and interests, the question becomes: which one is the true and undistorted Americanism?

Any ism needs a larger-than-life figure to be the face and the voice of the system, the identifiable practice, and the movement in which that particular ism is embodied. A U.S. president epitomizes what means to be an American and embodies what America is. He or she is a symbol, in a distinctive position to create an era and a culture. Since Trump's "Make America Great Again" and "America First" replaced Obama's "Yes We Can," the American culture has turned its tide from equity and inclusivity to hierarchy and exclusivity. The Trump presidency has normalized racially charged incidents through constant reminders of "us" versus "them" rhetoric. This rhetoric effectuates racial and cultural divides in this land and builds walls to make the horizontal America contained and "quarantined", and the vertical America enhanced and energized. It has become a daily routine that "this is my neighborhood," "this is my city," "this is my country" reverberate with "go back to Africa," "go back to Mexico," "go back to India," "go back to China." Trump's rise has made it loud and clear that this land is my land but no longer your land. Recently, a swastika-wearing man in Ulysses, Pennsylvania told a CNN reporter: "rural area spoke up when they elected Trump" and "this is my country." "By "rural area" he means a vast political base that supports Trump and sees him as the most visible and representative of this base. By "my country" he means that America exclusively belongs to "us", the Trump camp, and thus we have sunk into a Trump America and now have to play by its rules. A signature of acting-on-your-behalf is scintillated in a magnified Trump:

Trump appeals to his voters and supporters with a remarkable ego performance, as he sees American society and the world as the stage of his "Reality Show." He projects himself as an invincible winner and an untouchable tycoon in the business of real estate, a strong macho man of bravado talking tough, the protector, and the savior of a nation from the incursion and infiltration of immigrants and Muslims (Yang, 2017, p.4). ${ }^{2}$

Trump magnifies his individual persona into a larger-than-life and collective representation of an exclusive and vertical culture as well as of a divisive and turbulent era. He intends to set the world as the stage of his "Reality Show" so that he continues to play the protagonist at its center and continues to win. "America First" and "Make America Great Again" conceals the mindset of "Trump First" and "Make America Trumpian." In terms of race and culture, Trumpism has been long harbored in fear, bigotry, distrust and discrimination towards immigrants and people of color. Trump has now personified Trumpism undisguised with cheers of the alt-right, the white nationalist, and the KKK as well as with false hopes of those less-than-equipped with a 21st century mindset. All this, coupled with his showman's stage performance, enables Trump to create a tribalism to divide the country and build a wall to verticalize America. National security has become undistinguishable from the security of those who endorse core values of the alt-right, the white nationalist, and the racist. In disguise of Americanism, "America First" and "Make America Great Again" have made America more disjointed and more disconnected racially and culturally. Trumpism, in the name of Americanism, verticalizes one America while diminishing and dehumanizing the other-the horizontal one that Guthrie embraces.

Throughout America's history, race, economic status, religion, and sexuality among other core-defining forces have determined how to exercise "the unalienable Rights endowed by the Creator -life, liberty and the pursuit of happiness," known to each and every individual in this land. The nation was conceived from a horizontal ideal that we are all born equal and endowed by the Creator with the same unalienable rights; Guthrie's song emblematizes this horizontal ideal, which has galvanized many in building and expanding a horizontal America. At the same time, conflicting interests and competing values, associated with race, creed, color and gender, have shaped a vertical and nonnegotiable power structure, designed and implemented by winning and subsequently ruling groups. Time and again, the status quo of the vertical power structure has been questioned, challenged, and destabilized by the horizontal America. Since the beginning of the nation's history, the paradox of the horizontal and the vertical has programed Americanism with inherent duality, conflict, interplay, peaceful or not-so-peaceful confrontations and negotiations. Because of the two seemingly opposite directions-horizontal and vertical-in the same constitutional space, Americanism has never been a fossilized canon set in stone but always an energetic and regenerative force in taking shape, evolving, and transforming. By building and raising cultural, racial and religious walls, Trumpism incarnates an exclusionist, isolationist worldview, which disregards and disrupts the vital symbiosis of the vertical and the horizontal at the core of American culture, disfiguring Americanism.

To fully embrace Americanism, one needs to have a full and integral picture in mind and in sight: Guthrie's horizontal, ideal America as well as the vertical America that has been put forth by winners of history and maintained by ruling classes and 
institutions. Any attempt or practice to disassociate the two runs the risk of disfiguring Americanism in its very essence. This essay aims to grasp a full, integral and inherent picture of Americanism in response to Trumpism, well stylized and blueprinted in the slogans "Make America Great Again" and "America First." In doing so, we scrutinize what consists of the two Americas and what divides while unites them. Most importantly, we point out that Trumpism is a fake and disfigured Americanism that undermines and dislocates the vital symbiosis within the verticalhorizontal duality that has already made America great and unique, and that has already and will continue to attract countless dreamers to fulfill their American Dreams in this land.

\section{The raising of the vertical America and the making of Trumpism}

Trumpism has surfaced from the collision of the vertical and the horizontal Americas. At this moment of history, populists, conservatives, and anti-immigrants, anti-Muslim, anti-Semitic, and anti-LGBTQ individuals are rallying behind Trump's "Make America Great Again” and "America First” slogans. Subsequently, there surfaces a (mis)perception that American values and interests can somehow be neatly and uniformly delineated into a wall configuration, physically on the US-Mexico border and culturally far beyond. "Make America Great Again" has made nothing but Trump a U.S. president of the vertical America, and also had made "wall-builders" lined up against "wall-crossers." In the nation's cultural and political life, the proposed wall draws a cutting line between the Trump support base, dubbed as patriots and true Americans, and immigrants, Muslims, and all those "less American or un-Americans." This land is no longer made for you and me when there is a Trumpism between you and me. The Trumpism takes us right to the still bleeding wounds from history: who gets counted in and who gets counted out along the cultural and racial wall. The U.S.-Mexico border wall displays Trumpism openly and stretches Americanism into a disfigured and unrecognizable face.

Then, what is Americanism exactly?

Let us take a look of the possessives in Guthrie's lyrics. "This land is your land, this land is my land," Who exactly do the possessives "your" and "my" refer to? In other words, who are the owners of "this land"-the American land, land of opportunities, land of dream, land of freedom, and land of the brave? The claim and reclaim of the ownership opens up a plethora of stories of usurpations, oppressions, and contests, associated with economic interests, sociopolitical power, class status, gender, religion, race and ultimately, culture itself. The winner dictates the rules and the rules dictate the cultural ownership. In a country whose very lifeline depends on replenishment of fresh blood from successive waves of immigrants, the ownership of the land and the ownership of the very ideal embodied with this land-freedom and democracy-have always been claimed by winners of history. Winners in this land are typically from European (Anglo) ancestry and possess a longer history of immigration and settlement. Although American Indians are the original owners of the land and the earliest dwellers, they have found themselves at the bottom of the cultural and social pecking-order if counted at all, because they are simply not winners of history. The combination of winner and earlier settler secures dominance, power, and influence on the part of the white Anglo-Saxon Protestants (the WASPs). Most importantly, they set their foot in not only earlier than other immigrant groups but also proved to be more organized and more goal-oriented than later comers. The WASPs had an upper hand to claim the ownership of this land, thus institutionalizing their economic interest, social status, and religious permeation, and cultural establishment. Human nature also dictates that any group set up measures to protect, hold onto the territories demarcated by those of the same group. The presence of anyone different can anticipate "danger to oneself or to a group to which one belongs-including economic, racial, ethnic, religious, or other identity groups-it is among the oldest of human forces" (Meacham, 2018, p. 15). Thus Americanism, from its beginning, has been exclusively prototyped with the WASPs design. The Indians, the African slaves, the Asian railroad labors, the Hispanics, the Muslims, among many other groups have found themselves disadvantaged and marginalized, due to the blatant power hierarchy, the timelines of their arrivals, and the historical circumstances of their arrivals. They all have had to learn how to adapt to and fit with the "standardized," "erected," and "set-in-stone" Americanism by the WASPs. If not, groups and individuals, who differed from the WASPs in skin color, in religion, and in language, would be perceived as less American or simply as unassimilable aliens, if not a threat to the WASPs' dominance. The "standardized" Americanism as such leaves ample room for economic disparity, racial segregation, cultural hierarchy, and religious divide; it creates a vertical and exclusive America.

Paradoxically but in an extraordinary way, it was the WASPs who had brought the ideal of equality, freedom, and democracy to this land. They came with nothing but a vision for a land where life, liberty and the pursuit of happiness could be carried out uninhibitedly. They were first dreamers of the American Dream in its audacious horizontality. The birth of the United States was inextricably intertwined with a group of British Puritans who were adherent to Calvinism. Marginalized and alienated by the established Church of England and in conflict with the Catholics, they encountered political and social barriers in the ecclesiastical system to bring about the Puritan clergy. When Charles I dissolved the Parliament in 1629, "the Puritans, probably quite rightly, interpreted this as a hostile act towards themselves and their religious practices, and so many decided to leave England and settle in the Americas, where they could develop their own communities based on their own beliefs." 3 This group of people risked everything to cross the Atlantic, not unlike today's immigrants from troubled parts of the world in search for opportunities in this land for a better life. More than 400 years ago, the WASP immigrants landed on these shores. In the cultural genetic make-up of this country, it is not difficult to identify elements of courage, bravery, forward vision, and indomitable spirit for freedom. Above all, the British Puritans had a dream for a just and free society and a model "City upon a Hill" in their minds when John Winthrop gave his sermon in 1630 "A Model City of Christian Charity" to his first group of Massachusetts-Bay colonists. ${ }^{4}$ That was Winthrop's early American Dream to make Boston a model city for the world to watch and emulate. The British Puritans dreamed an American Dream so that they would not face tyrannical oppression and religious persecution, so that they could be their own masters to practice the religion of their choice and live the life of their preference. What could be more democratic, more individualistic, and more horizontal than these values? The irony, however, lies in that the innate cultural makeup did not permit them to share equal opportunities to immigrants of other groups who came to these shores at a later point, nor to the American Indians who are the original owners of this land, nor to the African-Americans whose labor force impacted the economic infrastructures of the colonial America. Once settled in New England, the Puritans started to build religious congregations and governmental bodies to proclaim, institutionalize, and secure their dominant position and their ruling place in this land. Since then, the WASPs have kept the American Dream horizontal for themselves but erected it to be vertical and exclusive for any other groups and individuals in this land. The 
double play has set out a cultural pattern that is both inclusive and exclusive, both individualistic and collectivistic, both democratic and hierarchic. The duality not only makes the WASPs culturally paradoxical and politically loaded but also has determined and affected how other immigrant groups are perceived, rejected, or accepted, by the WASPs and within themselves.

In a vertically horizontal America, Guthrie dreams that the ownership of American land and culture is meant to belong to all of those who have made their way to these shores in pursuit of life, liberty and happiness, disregarding their origins, colors of skin, backgrounds or social classes. At the core of Guthrie's American Dream dwell these unalienable rights that have been the founding and guiding force for this nation. Guthrie's Americanism is equalizing and leveling, and opens arms to those who dare to dream and are willing to risk and sacrifice to bring the dream to reality. As such, from the soul of Americanism emanates a powerful and hopeful message that we can be equalized through our shared humanity, that hierarchies can be flattened, and that barriers can be removed. Guthrie's song has given millions of marginalized individuals, underdogs, and "outcasts" a lyric space to hope, to dream, to live, and to fight. After nearly eight decades, Guthrie's voice has found its way into the nation's collective consciousness, and most significantly, it has challenged head-on the status-quo of ownership and entitlement of "this land," at various landmark historic moments, especially at the peak of the Civil Rights Movement as its rallying song. The melody has epitomized an American horizontal spirit that inspires anyone who fights for freedom and equality in this land.

Americanism encompasses both vertical and horizontal Americas; the two exist separately, jointly, intertwinedly. As a duality, the disjointment as well as the entanglement of the two, challenges an authoritative, standardized, closed, and unalterable definition of Americanism. If Americanism is a life energy, it grows, evolves, and transforms as the nation moves forward in history; it allows competing definitions that reflect the time and the context in which we live.

In the racially charged and culturally bellicose Trump age, more than ever we are in need to address, beyond our divides, what America should be and what being American means. Guthrie's lyrics unfailingly prove to be a timeless source of strength, hope, and inspiration when we confront unprecedented rise in racially biased attacks and discriminations. In the name of national security and American interest, Trump's policy of separating children from their families at the border, his "Muslim ban," among many other Trumpian practices, have reinforced and even normalized a culture of deep hatred, bigotry and exclusion. All this is a far cry from Guthrie's free, open, and sweeping America. The Trump wall, although physically located between the US and Mexico, culturally it symbolizes an unsurpassable barrier between cultures, races, and religions. It makes this land disjointed and dismembered; it disfigures the face of freedom and democracy. To examine Trump's genetic disfigurement of Americanism, we turn our eyes to Trump's cultural wall, which allows certain groups to enter and belong to this land and call themselves American while fencing off certain other groups. The Trump wall or Trumpism, centered on "America First" and "Make America Great Again," mutates into an Americanism that polarizes us and them and draws a dividing line in between.

John Higham (1920-2003), a prolific historian, made his mark with his work Strangers in the Land: Patterns of American Nativism, 1860-1925. He is regarded as a "founding father" of nativism, and by extension, an authoritative voice in Americanism, for generations of historians to study, emulate, and develop scholarship in the field. Timothy Meagher's article "Revisiting John Higham's 'Strangers in the Land': Comment" was published in 2012. He describes Higham:
He was a member of one of the rarest or, at least, best hidden of peoples in the twentieth century, white Anglo Saxon Protestant (WASP) natives of New York City. He grew up then as an American insider, but an outsider in New York, where almost everyone else was a member of a racial, ethnic or religious minority (Meagher, 2012, p. 282).

It is not difficult to discern that in the mind of a well-respected Americanist (Meagher) there is a distinction between insider and outsider of being an American. Higham grew up within the 20th century WASP group in New York, therefore, he is an "American insider," whereas everyone else of diverse background represents something that an American insider does not belong to and vice versa. Meagher's comments on Higham exhibit a culturally embedded paradigm, inculcated with the nativism that its "founding father" brought to light: Americanism is a cultural and ideological anchor exclusively meant for the WASPs or for the white and Christian. Everyone else may be around but cannot possibly be an essential part in the American narrative.

Simon Van Oort in his “'Strangers' Revisited: Reading Donald Trump through John Higham" ${ }^{5}$ digs into the roots of Trump's "America First" mantra and construct:

Foreshadowing the expressed foreign policy by the incumbent President of the United States, the National Association of Manufacturers confessed in 1920 that immigration might endanger the nation and exclaimed that policy must rest on "the needs and interests of America first"

Trump's "America First" is not exactly original but from a culturally genetic and historic make-up that builds the vertical America. The xenophobic and anti-immigration rhetoric has its origin in nativism that harbors white nationalism, populism, protectionism and isolationism. John Higham's seminal work Strangers in the Land: Patterns of American Nativism, 1860-1925, carves a breeding ground for the cultural nativism to take roots and grow in the nation's consciousness. Thus, a dividing line between "Americans" and immigrants is drawn, differentiating the vertical and the horizontal Americas. Each time the two cross each other, they polarize more into two major cultural and sociopolitical building blocs: conservative and liberal, with all their swings and variations in between.

Higham's Strangers in the Land deals with the American cultural identity in 1860s, when the intellectual circles held an "open gate" to immigrants in a welcoming mood while preoccupied with an American identity. During the window of 1860-1925 that Higham covered, immigrants, especially of Irish Catholic origin, flooded in. However, anti-foreign movements and parties broke out in New York and other parts of the country after 1835 and then evolved into the "Know-Nothing" (Higham, 1954/2002, p. 4) agitation of 1850's. These organizations were known as native American parties or simple American party (p. 4). Once nativists' philosophy was baptized as Americanism, other possibilities and efforts to define a culturally foundational precept have been shut out of the wall. Higham elaborates that the grand work of American party is "the principle of nationality" (p. 4), as proclaimed in one of the Know-Nothing journals in 1855, "we must do something to protect and vindicate it. If we do not it will be destroyed."7

If we translate these words into the 21 st century Trumpism, they would read: We are facing a national crisis to lose our country to people of color, of different religions, of different values, and of different languages. Trump is claiming that he is the protector of America, the guardian of American values, and the defender of our national interests. Hillary Clinton failed to capture the public imagination of a savior-protector-defender president and was beaten in the election. Indeed, Trump's 
support base is vast and deeply embedded in Higham's nativism. Fear and bigotry motivate and mobilize the base to exclude, reject, and alienate anyone or anything perceived "un-American," with or without an actual wall. The word "American" starts its mutation from all-embracing to specified and discriminatory inclusion/exclusion; that is, from horizontal to vertical. America no longer means the original signified-the ones named after Amerigo Vespucci. The earlier white English-speaking Protestants feared that their entitlement would be contested and stripped away by the later immigrants, and their establishment would be threatened by newcomers. Higham called the Protestant fear and resentment a "loss of confidence" (p. 158) for this nation. The outbreak of "nativism" was a Protestant or WASPs' reaction to such fears, resentments, and loss of confidence. In Higham's mind, no one else but the WASPs are the true Americans and are the only legitimate dwellers in this land. In Strangers, who is "native" and who is "foreign" in relation to this land is filtered with the WASPs as the central referential point and the ultimate cultural authority.

The vertical America, grounded on nativism, designed to set up a cultural hierarchy, and encoded in an exclusive blueprint of being American, is a formidable construct. Its genetic make-up backs Trump presidential campaign slogans fittingly and effectively. Trump played into a similar fear and a similar "loss of confidence" of many middle class Americans, who are typically white and left behind by the globalization. Many conservatives also find themselves highly receptive to "America First" and "Make America Great Again." The anti-immigration and antiMuslim sentiments have been stirred up. The alt-right and white nationalism have been geared up to kick the "strangers" out of this land. Donald Trump's former adviser Steve Bannon reincarnates Higham's nativism not only in a ghostly form as portrayed by Saturday Night Live but in a flesh-and-blood force of white nationalism. He fuels the alt-right, the KKK, and the neoNazi movement in the country. Bannon is unapologetically proud of his anti-immigrant ideology; in fact, he puts a glorified spin on it. He told a far-right gathering in France on March 11 that they should handle accusations of racism with pride. "Let them call you racists," Bannon said to the French National Front Party. "Let them call you xenophobes. Let them call you nativists. Wear it as a badge of honor." If Higham's nativism has made immigrants feel unwelcomed and unwanted, Bannon's "badge of honor" only deepens racial divide and broadens cultural distance. Bannon continues to build the vertical America with white nationalists at its center.

In the vertical narrative, nativism bestowed "honor" on the British Puritans and secured "honorable" dominance of the WASPs in the late nineteenth and the early twentieth centuries. A founding ideology of the vertical America was much in need then. As a result, the existential question about cultural ownership in this land had to be addressed:

Does nativism consist only of the particular complex of attitudes dominant in the anti-foreign crusade of the midnineteenth century? Or does it extend to every occasion when native inhabitants of a country turn their faces or raise their hands against strangers in their midst? (Higham, 1954/2002, p. 3)

By identifying WASPs as natives and nativists in this land, Higham unequivocally constructs a nativist ideology for the vertical America:

Here was the ideology core of nativism in every form. Whether the nativist was a workingman or a Protestant evangelist, a southern conservative or a northern reformer, he stood for certain kind of nationalism (p. 4).
The ideology connects nativism and (white) nationalism seamlessly; the two terms are now interchangeable synonyms. Leonard Dinnerstein and David M. Reimers indicate that Higham "had originally intended to write about American nationalism" (p. 6), but it turned out to be a daunting task:

....as he (Higham) examined his material further, he began to realize that American nationalism developed in-group and out-group formulations. The in-group was composed of those represented by the dominant white Protestant culture who turned against large-scale immigration from Europe after the 1880s.... He ended with a stunning and brilliant book about the rejection of southern and eastern Europeans who sought refuge in our country (Dinnerstein and Reimers, 2004, p. 6).

The in-group nationalism possessed a religious, linguistic, racial and ideological homogeneity that facilitated a nativismbased nationalism, while out-group formulation tended to be too diverse to have a unified narrative, and in fact, contradicted the in-group uniformity. Flash forwarding in time, as a diehard white nationalist, Bannon told the National Front crowd that he had learned from traveling the world that "history is on our side" and that "the globalists have no answers to freedom." Bannon's statement is a direct echo, across one hundred seventy years, of Higham's nativism and his intended nationalism. An exclusive cultural view has been canonized and inherited in favor of white supremacists, the alt-right, and the neo-Nazi. Most significantly, this worldview deepens and broadens the boundary between the two Americas.

Moreover, there is a missing element in Higham's nativism. The earlier Protestant settlers and Higham himself completely forget that the very first WASP settlers as well as of other European origins were also foreigners in this land and immigrants themselves. They dismiss, perhaps simply never on their cultural radar, that American Indians were the most rightful and lawful natives in America. If any native were to be called upon, American Indians would be the first to respond; but they did not have a voice in the construction of American nationalism. The forgetfulness about or the gross disregard of the American Indians in itself reveals an interplay of ethnocentricism, culturecentricism, and theocentrism; no one else but the then-WASPs were considered as the true Americans and de facto were in charge of the nation. The collective egocentric worldview contradicts and violates the founding ideal of this nation that all humans are created equal and endowed with the same unalienable rights to pursue life, liberty and happiness. The ideal of freedom and democracy was brought to this land by the WASPs, but ironically the very WASPs acted in every possible way to betray and disfigure the ideal when practiced on later immigrants, American Indians, and African slaves. Freedom and democracy for the WASPs while discrimination and exclusion for all others has set up a double standard; thus it has engineered the vertical America and concocted the horizontal one as a cultural duality. The case of the mid-nineteenth century Irish immigration testifies to the double standard in inclusion and exclusion:

He (a nativist) believed-whether he was trembling at Catholic menace to American liberty, fearing an invasion of pauper labor, or simply rioting against the great English actor William Macready-that some influence originating abroad threatened the very life of the nation from within. Nativism, therefore, should be defined as intense opposition to internal minority on the grounds of its foreign (i.e., "unAmerican") connections" (Higham, 1954/2002, p. 4)

Irish, together with Mexican and Chinese immigrants among other national origins, are labeled by Higham as "strangers" in 
this land. They are un-American, liabilities, and threat to "our" way of life and our values. They take away "our" freedom and opportunities. Catholicism is our enemy. This scenario looks a little bit too familiar, when one lives in Trump's America. The 21st century "nativists" are not too different from the ones in Higham's focal time period 1860-1925. The hegemony and ethnocentrism embraced by the WASPs in the mid-nineteenth century stirred up cultural, religious, and racial fear and resentment among the dwellers in the vertical America. The selfproclaimed and self-fashioned owners of the resources, institutions, and cultures of this land feared that Irish would take away their entitlement and opportunities; it is the same fear that many in the white middle-class have today that Mexicans and all other immigrants will do the same to them in the 21 st century. Higham called the fear "loss of confidence" (p. 158) and Trump capitalized on the contemporary loss of confidence in the U.S. and grabbed presidency. The then-bigotry towards Catholics parallels the nowbigotry towards Muslim. Higham's polarization of American vs. un-American based on national origins still molds antiimmigration sentiment in our time.

Embracing a similar homogeneity, contemporary nativists perceive themselves as authentically American and standard bearers of American values. Moreover, they claim and demarcate a cultural territory to include and exclude, thus considering themselves de-facto owners, defenders, and protectors of American people, culture, and society. In a cultural sense, Trump operates eerily "with intense opposition to internal minority on the grounds of its foreign connection," to quote Higham's words (p. 4) again. To rid the WASP's nation of internal enemies and minorities, the President's 2017 January executive order, "Border Security and Immigration Enforcement Improvement," directs the nation to build a wall on the Mexico-U.S. border. At the same time, his another executive order, de facto "Muslim Ban," directs the Department of Homeland Security and the State Department to lower the number of immigrant and refuse refugees from six Muslim majority countries. To fuel a vitriolic culture in order to appeal to his support base, Trump infamously called Mexicans rapists and criminals, and regarded immigrants from African (Haiti) countries as shithole countries. His attempts to revoke DACA status kill the American Dream of young immigrants. Trump's policies remind the country of the days of the 1921 Immigration Restriction Act against Southern and Eastern Europeans, Jim Crow Laws, the Chinese Exclusion Act, Japanese internment camps, glass ceiling, so on and so forth. The current cultural turmoil in the Trump era mirrors the one almost two centuries ago and carries on the same political and cultural agenda of the vertical America.

In Strangers in the Land, who is stranger and who is American is determined through the lens tinted with the nativist worldview. This worldview promotes an undemocratically appropriated, feardriven, and disfigured Americanism, and nativism is still much tinted with the 19th century WASP's ethnocentrism. In the 21st century America, who gets in the border wall to be counted as American and who gets blocked out as national threat now has to be screened by Trumpism-a resonance of the undemocratically appropriated, fear-driven, and disfigured Americanism, more than a century ago. In the public presentation "Steve Bannon Full Speech in France 10 March 2018 'history is on our side,",10 Bannon slammed Hillary Clinton as a failed globlist, and openly stated his position in relation with xenophobes, racist, homophobes, misogynists:

If you defend nation's sovereignty, they call you nativist; you argue for your freedom, they call you xenophobe; if you argue for your country, they call you racist. The thing of smear is over, let them call you racist, xenophobe, nativist... wear it as a badge of honor. ${ }^{11}$

This statement, on the surface, is decorated with patriotic, democratic, and noble vocabularies, but underneath there is a culturally coded message that this nation exclusively belongs to Steven Bannon and those of his cultural genetic make-ups. His sovereignty is the superiority of certain white nationalists and the alt-right over those who do not share the white supremacy worldviews; his freedom is a boundary-drawn and conditioned freedom, it is a privilege to be defended for some but not for all; his country is the vertical America only.

Trump's “America First" rhetoric disfigures Americanism in an even more deceitful and disguised manner. The rhetoric takes a central stage at a time when the rapid influx of immigration becomes an integral part of a globalized market, community, communication, and network. Many are still wrapping their heads around demographic changes and daily interactions with people who are different form them. Many still hold tight the belief that cultural identity relies on cultural hegemony, and social stability comes from an unchanging and static demographic landscape. Manipulating Americans' patriotism and singling out the setbacks of globalization, the rhetoric of "America First" and "Make America Great Again" indeed sounds redeeming and elevates Trump to a messianic figure to save and deliver America. However, in the cultural depth, "America" is used with specifically designated meanings for specifically designated groups; it refers to the vertical America only. It is loaded with multiple and embedded connotations in the vertical America as well as in the horizontal America. When white nationalism, patriotism, protectionism, nativism, and the alt-right become interchangeable synonyms, "America First" appeals to those who are afraid that their jobs and opportunities will be taken away by "foreigners" and their ways of life will be interfered by a different religion or people of non-white skin color. Many fearful individuals happen to be the 21st century WASPs and white middle class or lower middle class. Some of them may have lost jobs due to globalized trade and market. Some of them may have not got an opportunity to open their mental horizons educationally and culturally. Nonetheless, they all get the less-than-nuanced and less-thanprocessed message of "America First," as they believe that no one else but they are the only type of Americans and they are the America. Trump succeeded in winning their votes.

While "America First" means patriotism in the vertical America, in the horizontal America, it means renewed exclusiveness towards legal and contributing immigrants. An example in point is Macy's Inc. The retailer had discriminated against immigrant employees when verifying their eligibility to continue to work. Beyond legal requirements, extra and unnecessary documents were imposed in the name of national security and "America First." This resulted in "some affected workers being suspended, terminated, or losing seniority." 12 The employment discrimination based on national origins happens in the Trump time; it happened to Irish immigrants in the peak of nativism, also in the name of "America First." "America First" also connotes a different meaning to religiously diverse groups, the American Muslims in particular. If the word "America" is monopolized by the vertical America, does this mean that all Muslims should be regarded un-American at best and terrorists at worst? "America First" does not guarantee a place to be first for African-Americans, Asian-Americans, Hispanic-Americans, LGBTQ-Americans, Jewish-Americans. These groups are not located in the vertical America and do not fall into a blood-andsoil definition when scrutinizing their cultural belonging and ownership. 
Trump's most notorious act of "America First" in getting rid of the "internal minority on the grounds of its foreign connections" is perhaps the infamous and premeditated birther movement against former President Obama. The core of the vertical America simply could not and still cannot accept a Black man occupying the most powerful office in the world and being their commander-in-chief. In the land of democracy and freedom, they are simply not able to cross the color line, to use W.E.B. Du Bois's term coined in his the Souls of Black Folk in 1903. Obama's political rise is a head-on challenge to the racial, cultural, and political establishment and "norms," perpetuated for centuries by the white dominant and ruling class. Threatened, there was a widespread need to delegitimize Obama by proving that Obama was not born in the U.S., therefore ineligible for being a U.S. president. This would be the only way to get rid of such an existential threat. On the other hand, in the horizontal America, the election of the nation's first Black president was a watershed moment. Obama's victory signified the victory of the marginalized and horizontal America over the vertical America; it also gave the hope for the African-Americans and other minority groups to have a say at the core of the white dominant institutions. The incompatibility of two opposite cultural perspectivesthe white dominance and the victory of the marginalized-triggered an organized racism against the one whose job is to protect the very institutions and the very citizens who try to bring him down. As U.S. President, Obama had responsibilities to protect and defend both vertical and horizontal Americas, both his supporters and detractors. A twisted and disfigured Americanism situated President Obama in a position obliged to protect and defend the rights of the Trumpian nativists who aimed to reject, injure, and humiliate him because of his race. Taking Obama's Kenyan father out of context, Trump led the birther movement to illegitimize Obama politically, thus eliminating the threat from the horizontal America and protecting the vertical enclave. It was done in the name of the Constitution, national interests, patriotism, and "America First." Behind the birther movement, the ideology of Higham's nativism and white supremacism became resuscitated and more alive than ever. It is an ideology that does not accept racial equality but defends racial hierarchy. The birther movement has drawn an unmistakable color line between the two Americas. It reveals a still vigorous support base in the vertical America for nativism, white nationalism; it reinforces the rhetoric of "America First."

With all these exclusions, specifications, and discriminations, Trump's "America First" masks, twists, and disfigures the founding ideal of this nation that all men and women are born equal and endowed with the same unalienable rights. The more Trump and Bannon intend to defend the status quo, the more disfigured, reduced, and exclusive their Americanism becomes. The more followers Trump/Bannon have, the further the nation drifts away from the intended ideal of being American and the deeper the cultural boundary between the two Americas cuts in. Higham's racially and religiously motivated nativism incubates and fertilizes white nationalism, the alt-right, and white supremacism. He twists the blood-and-soil worldview and helps instill a culture of fear, distrust, paranoia, bigotry, and an ideology of white nationalism in the vertical America. If the outbreak of nativism is a cultural reaction to the loss of confidence in Higham's time, Trumpism is an identical reaction to the same sentiments and elements in our time. Trump's "America First" or Trumpism erects racial and cultural hierarchies and sets out to legitimize them, brings America to the pre-Civil Rights Movement era to "make America great again," sparks fear, bigotry, and distrust among Americans, and deepens the boundary between the two Americas. Trumpism is not Americanism, but a masqueraded white supremacism and nativism; it is a disfigured
Americanism in its vertical form. In fact, "America First" has proven to be one of the most un-American rhetoric and acts in the nation's history.

\section{The mapping of the horizontal America and the make-up of Americanism}

As an immigrant nation with massive racial and ethnic diversities, we have been confronting inevitable questions and choices: who or which group owns the American culture? How should one draw the contour(s) and paint the color(s) of an American cultural identity? Attempts to answer these questions invariably drive us into some irreconcilable frameworks of constructing Americanism. This essay has grouped them into two main perceptive modes: the vertical and the horizontal. The vertical America needs a fixed boundary for hegemony and stability to maintain its status quo and authority. The horizontal America is a de facto byproduct of the vertical one; it does not have many choices but an open and fluid boundary to collect and gather everything and everyone that is not desired in the vertical America. The fluidity keeps the horizontal America inherently malleable, so malleable that it can even potentially permeate the vertical America if the time is right. However, paradoxically, both Americas use the same lenses looking at the divide between them. These are racial lenses. The two Americas have been "genetically" constructed and set apart by an intended color line, again to borrow Dubois's term. In both Americas, the color line has interwoven with and drawn together with economic, sociopolitical and cultural lines. To zoom into the horizontal America that is now facing and confronting Trumpism, a culturally cognitive frame on race needs to be established.

In any society and culture, there are myriad boundaries and hierarchies that induce divides, competitions, and struggles for control, ownership, and entitlement. The single most divisive element is perhaps race. Unlike other defining elements, racial difference is immediately noticeable and recognizable on the surface when people come into contact in conducting daily life, national life, and cultural life. If one is not equipped with racial literacy, the perception can easily be governed by what is immediately seen to the naked eye, skin color for example, or by stereotypes with all the bias and prejudices. A lack of empathy, knowledge or education likely impairs our perception and prevents us from formulating beyond-the-surface judgment and understanding. Race is the first separator and often a misled one to hierarchize cultures, belief systems, and people. Race stands out and cuts fatefully more than religion, gender, political ideology, and social classes. Jacksonian racism towards American Indians, Spanish Conquest of the Mayan and Incan civilizations, British colonization in Africa, Asia and other parts of the world, and many other colonial and neocolonial patterns testify to the fact that race builds social order, institutional structures, and cultural hierarchies.

In the specifically American context, the color line is both a converging and diverging front for the vertical and the horizontal Americas. When the Mayflower landed on these shores in the 17th century, the English Puritans came into contact with the American Indians. When African slaves were brought to this land during the 17 th and the 18th centuries, white, indigenous, and black races met but not blended. Then, the rest is the great American immigrant story that pertains to no race unknown on the planet. In a multi-racial and multicultural country like ours, race shapes our individual and collective identities, reveals the core of our beings, constructs power relations, retools ideologies, heightens our sense of equality and inclusion, defines liberal and conservative politics and associated policies, transforms institutions, and creates cultural tide waves. Most important, race has 
put the ideal of democracy into unmatched tests, time and again; race has brought to light unseen color lines drawn in our minds and in the fabric of our society, which deter the dwellers of the two Americas to cross back and forth and reach out to one another. American history is a racialized history in all its forms, shapes, and colors; it gives rise to the vertical and the horizontal Americas.

Víctora M. Rodríguez in reviewing Ronald Fernandez's 2007 book America Beyond Bland and White cuts to the chase: "While America is a nation of immigrants, immigrants have been racialized, eulogized, and despised" (Rodríguez, 2009, p. 264). “...Fernandez, in leading us through this journey through the history of race in the United States, is also able to remind us of the interconnectedness of immigration, culture, and race" ( $p$. 265). In a multitude of colors and shapes, race, culture, and immigration interact as major mobilizers in the horizontal America. Unlike the vertical America that dictates what Americanism is, the horizontal Americanism, if at all, is deemed by its counterpart to be culturally "alien," "foreign," and simply "un-American," as it does not fit with the vertical "standards" and institutions erected by the vertical America. In the absence of an explicitly unifying Americanism, the "colorblind" ideology has been adopted to synergize the disenfranchised and marginalized; it aims to erase the color line and its associated economic, sociopolitical, and cultural lines, to unite the horizontal America and to dismantle "racialization and racialized thinking" (p. 265). The participatory entities and components vary at different historical moments as the cultural and sociopolitical landscape shifts and transforms. Nonetheless, each wave of the "colorblind" initiative drags in and filters out new elements of race, culture, and immigration. In facing Trump's racially and culturally coded and masked "America First" and "Make America Great Again," a colorblind approach proves to be still vital to hold the horizontal America together as an authentic definition of Americanism. To examine how colorblindness concocts the horizontal America, let us focus on two iconic figures who have already shaken the foundation of the vertical America, and set up an architectural design for the horizontal America: Martin Luther King and Barack Obama.

The two-America concept is not alien to Dr. Martin Luther King. Dr. King purposefully engages in an ecumenical and unifying approach. In 14 April 1967 at Stanford University, Dr. Martin Luther King Jr. spoke to supporters participating in the "Salute to Freedom" event, organized by the Local 1199 in New York City. The speech itself was titled "The Other America." 13 First, he depicts the prosperous and privileged America, or the vertical America that we are theorizing in this essay:

... there are literally two Americas. One America is flowing with the milk of prosperity and the honey of equality. That America is the habitat of millions of people who have food and material necessities for their bodies, culture and education for their minds, freedom and human dignity for their spirits. That America is made up of millions of young people who grow up in the sunlight of opportunity. ${ }^{14}$

Although no direct mention of whites and vertical society, words like prosperity, equality, food, culture, education, freedom, dignity and opportunity are more than enough to describe the exclusive and privileged white America high above. Democracy thus is an entitlement and property meant for and owned by certain Americans, but not all of them. The very ideal of being American thus belongs exclusively to those cultural "insiders" on the top, who have means and access to education, resources, and institutions. Needless to say, African-Americans are not among these "insiders" but outsiders of the America "flowing with the milk of prosperity and the honey of equality."
Then, King turns his head to the other America-the marginalized and disadvantaged under the same sun with the privileged:

But as we assemble here tonight, I'm sure that each of us is painfully aware of the fact that there is another America, and that other America has a daily ugliness about it that transforms the buoyancy of hope into the fatigue of despair. In that other America, millions of people find themselves forced to live in inadequate, substandard, and often dilapidated housing conditions... In this other America, thousands, yea, even millions, of young people are forced to attend inadequate, substandard, inferior, quality-less schools, ...not because they are dumb, not because they don't have innate intelligence, but because the schools are so inadequate, so overcrowded, so devoid of quality, so segregated, if you will, that the best in these minds can never come out. ${ }^{15}$

Once again with no mention of any specific race or ethnicity, King depicts the living conditions and education disadvantages of the deprived Americans. He points out the segregated school system as the bottom line that divides the two Americas; that is the very color line that divides American culture in the impressionable and formative young minds, whether black or white or brown. There is a number of scholars in Cultural Studies, who regard the racial line as fundamental in the complex construction of American culture. Richard Merelman states:

In the United States, isolation between the races has been more complete than isolation along gender, class, or white ethnic lines. Federal law did not even require blacks and whites to have access to the same public schools until 1954; by contrast, men and women, rich and poor, Poles and WASPs were never legally segregated in public schools. Nor were these groups ever as segregated in practice throughout the range of life as white and blacks still are today (Merelman, 1994, p.5).

It is the school system where the color line starts to be drawn socially and culturally, singling out African-Americans as the cultural other and sending them the message of a not desired race. As children, white and black, grow up in such a black/white segregated educational system, their sense of segregation, racial prejudices, and cultural ethnocentricism grow up together with them. Merelman explains the racial disparity between the white and the black:

For example, 39 years past Brown v. Board of Education, most whites and blacks still attend different schools, ... This severe isolation has enabled whites to control the definition and flow of cultural capital in most universities, in the media, and in primary and secondary schools. (Merelman, 1994, p. 5)

King further points out, the racial segregation creates two sets of language that describes the same economic condition and social status in the two Americas:

The fact is that the black man in the United States of America is facing a literal depression. Now you know they don't call it that. When there is massive unemployment in the black community, it's called a social problem. But when there is massive unemployment in the white community, it's called a depression. With the black man, it's "welfare," with the whites it's "subsidies." This country has socialism for the rich, rugged individualism for the poor." 16

The two Americas speak two different languages and they do not understand each other. Are we going to leave them alone 
forever in discommunication and miscommunication? There is no doubt that King intended to be the "translator." He understood that the translator must speak both languages, must be an insider of both Americas, and must be trusted and respected by both. However, in his time, race divided Americans into steeply unequal economic and social statuses, and distributed power and authority on a sharply uneven scale. He knew that singling out the African-Americans, whether defending or discriminating them, would set up the group as an isolated and point-blank target. By correlating with other marginalized racial and religious groups, King would have a broadened support base for his cause and maximize the chance for his dream to come true. To be a translator of different Americas, he avoided stepping on the most divisive line of race, instead he used the universal language to speak economic interest, livelihood, job and opportunities. This language builds a shared front and unites all disadvantaged Americans in their fight for equality and justice. This language eradicates the vertical barriers and breaks up silos. To overcome racial barriers - the most fateful demarcation of cultures and institutions, and also to earn the trust and respect across races, King practiced a relational "colorblindness," which is the core of his Americanism and his American Dream.

Race cuts the nation into fragmented and irreconcilable Americas, and yet each holds onto its own ideal of Americanism and American Dream. Not unlike the vertical America, the horizontal America cannot surpass the color line either. As much as King desires to expand the racial and cultural support base to correlate with diverse racial and ethnic groups, he falls back time and again to the color line between the white and the black. The deep historic wounds that the nation has sustained pose unique challenges to heal racial scars and to decontextualize economic statuses and social classes from the racial milieu. Nonetheless, in uniting the horizontal America, the African-American experience has become "yardsticks" and "benchmarks" of marginalization, discrimination, and rejection, brought upon by the vertical Americanism. Other racial groups and new arrivals in these shores in many ways identify themselves with the African-Americans in their struggle for equal rights, justice, and acceptance in both the vertical and horizontal Americas. They all share an American Dream from the margins. This is an achingly beautiful dream envisioned in King's "I Have a Dream." Anchored in the African-American experience as home base but not confined to it, once again, King calls for a rainbow like coalition and unity in the other America:

Now, I said poor people, too, and by that I mean all poor people. When we go to Washington, we're going to have black people because black people are poor, but we're going to also have Puerto Ricans because Puerto Ricans are poor in the United States of America. We're going to have Mexican Americans because they are mistreated. We're going to have Indian Americans because they are mistreated. And for those who will not allow their prejudice to cause them to blindly support their oppressor, we're going to have Appalachian whites with us in Washington. ${ }^{17}$

Back and forth from the African-American to the color-palette of America, King attempted to erase the color line and "baptized" the movement of America's poor across races-our "Poor People's Campaign." His rainbow-like "the other America" merges with Guthrie's this land. African-Americans, Puerto Ricans, Mexicans, and other workers of color are citizens of the poor and disenchanted "Other America." He made a call for his multiracial, multi-religion, and multicultural "Poor People's Campaign" to resuscitate the dream, ignited with "I Have a Dream" in 1963. King's dream of racial equality becomes the synonym for the American Dream of the Other America; "I Have a Dream" defines the American Dream and Americanism in the horizontal America. Fight for jobs, for equal wages, equal opportunities, and most fundamentally, fight for the judgment of our character past the color of our skin. King's ultimate dream was that "one day this nation will rise up, live out the true meaning of its creed: we hold these truths to be self-evident, that all men are created equal." The color line will ultimately be erased in our cultural minds, so he believed. His "the Other America" is the platform for him to "... deal with all of this by using as my subject tonight 'The Other America.' "18

King's purposeful "colorblindness" is carefully constructed on shared economic interest and struggle; it enables him to transcend the African-Americans' sorrow and pain, and reach out to a broad range of economically disadvantaged Americans, including poor whites. His Americanism epitomizes a horizontal American Dream that everyone and anyone from a marginalized position can have a dream, disregard their races, religions, and origins. King's "The Other America" gives an inclusive and flattened definition of Americanism-a horizontal Americanism from the margins. King's Americanism empowers and dignifies disenchanted and disenfranchised citizens to aspire, dream, and act, just like the citizens in the vertical America. It culminates in "I Have a Dream" for everyone. It sends a powerfully democratic message: we are more similar than different although in two Americas. King left an undeletable blueprint in the horizontal Americanism. His trans-racial spirit and qualities, coupled with non-violence, heal a divided America, build trust and connection, and bring Americans together as United States of America.

In the 21st century, racial tension, cultural contest, and religious divide are far from over. Are they any different from King's time? While these themes remain disturbingly unavoidable and continue to be real in the nation's sociopolitical life, there has emerged a cultural antithesis in racial and cultural politics: Donald Trump and Barack Obama. The Trump age polarizes even further the vertical and the horizontal Americas. Trump's rise revives the hierarchic and exclusive nativism, incarnated in the white nationalists, the alt-right, the neo-Nazi and the KKK. Trumpism fuels the vertical Americanism and channels the ghost of Higham's nativism. Led by individuals like Steven Bannon and Richard Spencer, a renewed effort to rebuild an America that exclusively belongs to white men, is well underway. Trump's presidential victory is the victory for the vertical America over the horizontal one.

As Trump's cultural antithesis, Obama's presidential election in 2008 marked a victory too, a victory that epitomized the horizontal America, but it is not a victory over the vertical America, a victory that has reinforced the horizontality within the vertical America. Obama's rise was a watershed moment: a moment of white Americans' transcendence of the color line, a moment of the fulfillment of King's dream of racial unity and brotherhood, a moment of African-Americans' dignity and pride, and a moment of the acceptance of the horizontal America by the vertical one. Given the statistics, securing white voters is crucial in any successful national campaign. African-Americans, Asian-Americans, Hispanic-Americans and American-Indians would be needed too but can well be statistically secondary. In relation to the U.S. racial politics and cultural identity, Obama's success has proven that white Americans are capable of erasing the dividing lines between the two Americas; black and brown Americans are eager and ready to enter the center of the establishments and institutions as whites' equals. Obama's victory proves that permeating the vertical America from the horizontal one is possible and the color line is shiftable. He embarked on an uphill journey, not only crossing the fatal line but also climbing from the below-zero periphery to the top of the erected center. 
What Obama has achieved is a quintessential American story that belongs to both Americas.

If MLK's horizontal Americanism is anchored in his "colorblindness" and in his command of a cross-racial language to speak to the economically disadvantaged Americans, how is Obama's Americanism grounded? If MLK fought for his transcendental and ecumenical dream for cultural unity and racial brotherhood, what does Obama's American Dream consist of? We enter Obama's horizontal America through three open and connected doors: patriotism, hope, and "colorblindness" a la King, squarely facing his antithesis Trump/ Trumpism.

Obama's patriotism is the core of his Americanism. A biracial kid, from early on, he has always been conscious about the color line that regards and excludes him as an outsider. In the vertical America, his skin color looks "un-American" and his name Barack sounds "un-American" too. By default, he falls into the horizontal America. Like a typical dweller there, he forges a worldview that recognizes extra effort and additional struggle entailed to achieve what is considered acceptable and successful in the vertical America. The family and travel experience in his young age has made him recognize the fact that the two Americas do not start from the same departure point. His Kenyan father was not much of a presence in his upbringing; but the father's American Dream to see this land from Kenya as a beacon of freedom has passed onto the son. It was mainly his white mother and white maternal grandparents who imbued him with another American Dream, a typical dream of the white middle-class Americans. The black Kenyan father's American Dream, the white American mother's cosmopolitism, and the white grandparents' American Dream, all these values and beliefs have converged together in the making of the future president of this country. Obama's Americanism has multiple nurturing grounds, which allows him to be equipped with culturally comparative and integral views. After all, it was in the American soil where he was born and it is in this land that he has found himself and his American Dream has come true. Obama's patriotism is characterized with the desire for a home, where he is accepted with dignity and warmth, where everyone is judged by his/her character not by skin color, and where everyone has a chance to dream and to hope and to become what she/he is meant to be. All this has evidently grown into his unwavering belief and faith in the greatness of America.

These multiple nurturing grounds for Obama, however, confuse and dislocate many white natonalists, nativists, isolationists, protectionists who happened to be Trump supporters. In their worldview, because of his diverse background, because of his skin color, and because of his "funny name" (Obama, 2006, p. 362), Obama has to be an outsider and cannot possibly claim equal American citizenship. If he does, he would be a threat to and undermine the Trumpian establishment and institutions. Even Obama's birthplace had to become a question in the America where his mother and maternal grandparents belonged to. Had Obama's father been a white Protestant European, would he have been subjugated to the racist and discriminatory birth verification? Trumpism has reduced being American to the membership of the white nationalist/nativist club. On the contrary, Obama's patriotism, anchored in the plurality of cultural and racial perspectives, has expanded the horizon of Americanism, and enshrined it in a 21st century light. Trumpian supremacists and isolationists consider themselves as sole owners of American culture; they pose a vertical imposition and a hierarchic exclusion in defining and determining who is eligible to be American. This is done to protect the "purity" of the club and to maintain the Trumpian ruling position. The 21st century nativism is thus carried out in the name of Americanism, in its disfigured form.
Obama's Americanism comes from an injured and denied patriotism that intends to recover, heal, claim, and become integral and whole. His patriotism cannot be separated from the belief of a holistic and democratic humanism that can only be regained by the ideal of this land. It goes with, first and foremost, hope; it goes with unconditional love; it goes with faith. In his keynote speech at the 2004 Democratic national Convention, "Out of Many, One," Obama defines his hope-based patriotism:

I'm talking about something more substantial. It's the hope of slaves sitting around a fire singing freedom songs; the hope of immigrants setting out for distant shores; the hope of a young naval lieutenant bravely patrolling the Mekong Delta; the hope of a millworker's son who dares to defy the odds; the hope of a skinny kid with a funny name who believes that America has a place for him, too. ${ }^{19}$

He wholeheartedly believes the greatness of the country, as this is the place where he makes and writes his and our American story. He knows no other place in the world that could possibly be his home and make his heart fonder. "My heart is filled with love for this country (Obama, 2006, p. 362)," and that love propels him to hope and to reclaim the American Dream:

I stand here knowing that my story is a part of the larger American story, that I owe a debt to all of those who came before me, and that in no other country on earth, is my story even possible. $^{20}$

By positioning his personal narrative in the historic and cultural lineage of the country, he depersonalizes his individual background and story, and inserts himself as a connecting link of the two Americas, similar to King's role of cultural translator and synchronizer of the two Americas. Thus, “... a skinny kid with a funny name" "believes that America has a place for him, too," and thus different types of personal American Dreams fuse together into one big collective American Dream. The nation was touched by the speech and the youth was electrified by the message of hope. Right after that, Obama rose to national prominence as a notable Illinois senator.

Equivalent to King's dream, Obama's hope quickly earned an iconic place in the 21st century narrative of Americanism. Both are charged with spiritual power beyond politics; both focus on the commonality in the human nature rather than the differences. Deborah Atwater argues:

I am defining a rhetoric of hope as the use of symbols to get Americans to care about this country, to want to believe in this country, to regain hope and faith in this country, and to believe that we are more alike than we are different with a common destiny and a core set of values" (Atwater, 2007, p.123).

However, the dividing line between the two Americas can only be erased once racial trust, mutual respect and understanding are established. Law and affirmative actions bring legal sanctions to regulate the behavior or the speech that violates the Constitution, but cannot achieve interracial unity, racial equality, and "the politics of hope"21 at the depth of the nation's psyche and at the core of a human being. It takes each individual's willingness, initiative, and commitment to achieve true racial integration and cultural unity, there has to be a spiritual connection across races for a coherent and undisfigured Americanism, transcending the obstacles that races, religions, and social classes have erected. Obama's Americanism signals that it is possible that two Americas connect with one another and it is possible to cross the color line between the two, because of the greatness of our country that he believes and because of his unwavering faith on the ideal of freedom and democracy. His Audacity of Hope is an 
autobiographic account of his journey, sent off by his father, mother, and grandparents, from being an outsider to the driving seat that made American history. Obama's Americanism is thoroughly incompatible with Trump's Americanism. One is horizontal and one is vertical. One is still much of an ideal and one remains in the depth of the nation's psyche. History has given birth to two Americas in the United States of America, sharing the same nation and the same Constitution.

Like MLK, Obama is "colorblind" too, in reclaiming the American Dream and reaching out to fellow Americans across the color line(s). "There is not a black America and white America and Latino America and Asian America-there is the United States of America." These lines have been quoted again and again in cultural politics and cultural studies. Obama's reclaimed American Dream is a processed colorblind dream that bears relevance to all Americans including white nationalists, isolationists, and protectionists. Different from Trump's Americanism that amplifies racial division and creates cultural bigotry and distrust, Obama's Americanism projects a uniting, liberating, and uplifting power:

...a vision of America finally freed from the past of Jim Crow and slavery, Japanese internment camps and Mexican braceros, workplace tensions and cultural conflicts-an America that fulfills Dr. King's promise that we be judged not by the color of our skin but by the content of our character. (Obama, 2006, p. 231)

Galvanized by King's spirit, Obama touches Americans' shared humanity and sends a universal and inclusive message of a marginalized voice, moving into the center, to be heard, to lead, and to shape history. If the vertical America's universal values are about imposing certain groups' monolithic authority to others, out of fear to lose dominance and out of the need to be in control, the horizontal America's universal values are about bringing to light our mutually resonant desire for dignity, respect, and opportunity across races and cultures. If Trump builds a wall to divide, Obama attempts to tear down that very wall to unite. He ran for the highest office in the land to cross the color line and bring the two Americas together in dialog:

Perhaps more than any other time in our recent history, we need a new kind of politics, one that can excavate and build upon those share understandings that pull us together as Americans. (Obama, 2006, p. 9)

He believes that "we can ground our politics in the notion of a common good" (9). Our skin colors may be different, but at the core of our beings and characters, we share the same human nature and dream the same dream. No one wants to be rejected and counted out, no one wants to feel like an outcast and alien; in fact, everyone in different ways and in different contexts aspires to grow happier, stronger, more successful, and more relevant. Across cultures, this is a universally shared human nature. The American land symbolizes the ultimate acknowledgement of shared humanity and embodies the ideal that allows room for expression and development of our humanity. Obama captures that essence of being American. These innate ideals thus have become the American Dream that has attracted Obama's father and millions from around the world to these shores for as long as the country has ever existed. The American Dream, as a timeless pursuit, "is a paradigm distilled from a collective origin and the consciousness of a group; ..." (Yang, 2014, p. 104):.22

A dream brought a nation and a culture into existence; then a group of dreamers created a dream land only to attract more dreamers to come and create more dreams to live for... It was a dream for a life not being persecuted and coerced that brought a group of Puritans who risked their lives to arrive at these shores; it was a dream that kept the pioneers enduring the harshness and build something from nothing in the New World (p. 104).

Obama's American Dream is a spiritual unifier that glues people from different walks of life together; it intends to be an eraser that erases racial and religious divides; it aims to eradicate social and cultural inequities and hierarchies. The shared hopes, goals, sorrow and joy make the American Dream connect human commonalities rather than alienate fellow human beings because of different skin colors, religions, languages, traditions, and worldviews.

When facing the reality of two (or multiple) Americas, race, religion, gender, tradition, wealth, social classes, and other dividers incessantly cut, draw, and shift the lines of inclusion and exclusion. In a multi-layered and crisscrossed boundary drawing, exclusion and ejection overweight inclusion and acceptance, especially for the African-American community. Our society has repeatedly failed to see that the promise of justice and freedom for all people has not yet been completely delivered. As long as the vertical America is more concerned about the monopoly of culture and the status quo than about equality and inclusion, the horizontal American will remain dismissed and subordinated to the grand and authoritative narrative of Americanism. The vertical Americanism with its chopping, cropping, and cutting features disfigures the sense of self for those who are not fit, undersized or outsized. This country has not yet been able to erase these divides but tried time and again to minimize and heal the cutting wounds. Americanism has always been a cultural ownership. The one who owns it gets to have a say, claims power, gets in charge of institutions, and ultimately, shapes culture. Obama redefines Americanism by giving hope that our shared humanity can dream the same dream, and every legal citizen in this country is entitled of the cultural ownership, whether from the vertical or the horizontal America.

In stark contrast with Trump's name callings to disparage immigrants and people of color and building walls to "make America great again," Obama's horizontal America sets up a grounded while relational paradigm for a $21^{\text {st }}$ century cultural identity. He first roots himself in his black identity and then reach out horizontally:

I can't help but view the American experience through the lens of a black man of mixed heritage, forever mindful of how generations of people who looked like me were subjugated and stigmatized, and the subtle and not so subtle ways that race and class continue to shape our lives (Obama, 2006, p. 10)

$\mathrm{He}$ is able to anchor himself while relating to others horizontally from their perspectives. For white Americans, he displays a remarkable optimism: “... That whatever preconceived notions White Americans may continue to hold, the overwhelming majority of them these days are able-if given time-to look beyond race in making their judgments of people" (Obama, 2006, p. 235). For immigrants, he opens his arms: "I am your friend" and "you embody the American dream" (pp. 260-261). At the same time, Obama's American Dream forges common bonds and demands patriotism: "We can insist to those already here that with citizenship come obligations-to a common language, common loyalties, a common purpose, a common destiny." To Obama, "America is big enough to accommodate all their dreams" (pp.268-269). There is a distinctive spiritual element in his American Dream, that is, diversity in unity and unity in diversity.

Obama's Americanism heals the historical wounds and stiches the current divides. He carries on King's dream. More than what 
King has done, Obama has the audacity to develop his patriotism and Americanism into a politics of hope in the heart of the established institutions. His presidency has transformative effect on the 21st century American culture. The subtitle of his Audacity of Hope reads "Thoughts on Reclaiming the American Dream." Indeed, it was a lost dream recovered and reclaimed with his presidency.

\section{Conclusion}

Duality consists of two opposites in interaction-in mutual rejection, in mutual sculpting, and in mutual transformation, all in a shared, simultaneous, and coexistent sphere. Together, they form a willing or unwilling relation, sometimes with confrontation and bloodshed, sometimes through negotiation and manipulation, and sometimes through communication and connection. Duality does permit a fixed and unmovable divide between the two opposites as the constant interaction of the two shifts, erodes, and redraws the divide. By nature, the duality of the vertical and horizontal Americas is not designed for the color line to separate and hierarchize them, but to weave, stitch, and reshape them, in spite of all seemingly irreconcilable barriers and conflicts. The following example from a recent $\mathrm{CNN}$ articles testifies to the inherent invalidity and dysfunction of the color line in American culture.

The article, "He came to this country with \$200 and hope. How Khizr Khan's American dream led him into a battle with Trump," by Moni Basu Basu, (2018), reads:

He (Mr. Khan) arrived in America in late 1979, carrying a single silver Samsonite suitcase and \$200 in his pocket. The life he led in his adopted homeland was, by all counts, quiet and simple, though it was far from plain. He was a hardworking Pakistani immigrant who had felt the sting of martial law and developed a deep love and respect for the Constitution of the United States; he eventually realized his dream of graduating from Harvard Law School. He, along with Ghazala, his wife of 43 years, raised three sons, one of whom deployed to Iraq as an Army captain and returned home in a coffin. ${ }^{23}$

Mr. Khizr Khan, a lawyer and a Muslim American, has left the nation an undeletable image and an unforgettable voice at the 2016 Democratic National Convention. His son, Army Cpt. Humayun Khan, born and raised in this land, sacrificed his life for the country. As a Purple Heart family, the Khans "are proud American citizens," Khan said. "It's the values (of this country) that brought us here, not our religion. Trump's position on these issues do not represent those values." When Trump calls a de facto ban on Muslims entering the United States, there is an underlying color line: only the vertical America is patriotic, therefore, the white and Christian are patriots; an immigrant, non-white and non-Christian, at best does not belong to this land, and at worst is a suspect of terrorist, who poses threat to freedom and democracy and to the security of the vertical America. Mr. Khan, in Trump's world and in Trump's language, should be classified as outsider of "our" culture, "our" race, "our" religion, and "our" way of life, or perhaps a likely terrorist, synonym with Muslim. To many who embrace the horizontal America and to some in the vertical America, Mr. Khan's loyalty to this land, his understanding of the US Constitution, and his pride for being an American are evidently exemplary. However, this is unconceivable and unacceptable in a cultural mind hardwired with nativist and white supremacist values. How can an immigrant, an individual of color, and a Muslim love this country as much, if not more, as a white Christian who was born and raised in this land? How can the Khans live and die in order to defend the
Constitution of the US, freedom and democracy? Mr. Khan's voluntarily acquired Americaness powerfully breaks and erases the color line that draws apart the two Americas and confronts head-on Trump's disfigured Americanism that exclusively pertains to the white and Christian vertical America.

In the crisscrossed currents of race, culture, and politics, the 21st America constantly challenges the assumptions of the two mutually exclusive Americas. In the case above, the duality of the vertical and horizontal Americas enters a new phase of interactions, displaying more of a mutual definition and dependence than mutual rejection and exclusion. In the case of Khizr Khan, the love for the U.S. Constitution and the country is so unconditional and powerful that it crosses race and religion, and crosses the boundary of life and death. The vertical America is built upon the nativist ideology and self-proclaimed exclusive patriotism. Then, will it accept Mr. Khizr Khan, an immigrant of Pakistani origin and a Muslim American, as peer among white patriots? Wouldn't the vertical America ascribe Mr. Khan's "un-Americaness" to the unwanted horizontal America, put him into his place-the culturally unfit group, and even consider him a threat to national security because of his religion? Any attempt to address these questions triggers out whirlwind and emotional reactions nationwide. No American, whether from the vertical or horizontal milieu, can be exempt from this soul-searching process to confront oneself, rather than finger pointing the other.

Nonetheless, Khan has risen to be an icon of the American way. The Trump era hardens the color line and broadens the division of the two Americas, but also, for better or worse, brings the two together in the cross-racial and cross-cultural patriotism that the Khans personify. This is precisely how the duality of the two Americas functions and it reveals a more profound truth beyond race, religion, and politics; it is our shared humanity that makes us more similar than different. Whether through hatred or love, we connect while dividing and discriminating. The shared humanity is colorblind and does not discriminate by race, religion, nor politics, but paradoxically is also color sensitive at the same time. The shared humanity always revolves around the dichotomy us/them, my interests/others. When my/our existence eclipses race, religion and politics, the shared humanity dismantles the structures and configurations of the two Americas and deletes the divisive color line. In Mr. Khan, the shared patriotism erodes the boundary between the two Americas.

Americanism in theory allows ample room for human duality to play out, negotiate, and transform. The Statue of Liberty "takes the hand of the tired and poor, leads the huddled masses to breathe free, and welcomes the homeless and tempest-tossed," as penned by Emma Lazarus in 1883 on the tablet at the base of the Statue. Americanism gives hope for a sense of belonging and acceptance disregarding race, creed, gender, social classes. The Americanism from the horizontal America is open, malleable, and also vulnerable. It attracts individuals of all walks of life and from all corners in the world. Although racial "legitimacy," cultural "fitness," financial resources, and education opportunities are often questioned, the horizontal Americanism does not recognize the color line and matches the ultimate definition of Americanism. Both Martin Luther King and Barack Obama acknowledge shared humanity as a base to erase the color line and to link the two Americas. Although mistreated and abused by the vertical America, the two American cultural icons did not set out to antagonize or compete or exclude, but to reach out to and earn respect from the oppressors and abusers, as they focused on the shared humanity and the commonalities in all Americans.

The Americanism from the vertical America is hierarchic and sets structures and boundaries to exclude and to maintain racial and cultural "purity." Therefore, the vertical Americanism is an authoritative and "heresy" filtered narrative, designed to rule, to 
impose, and to dominate. By tracing back history and Higham's nativism, we recognize cultural mutations that Trumpism has emboldened-white supremacism, white nationalism, isolationism, protectionism, and the alt-right, the neo-Nazi, and the KKK. Nativism explains the roots of the current cultural turmoil in our society. The vision in the vertical America tends to be static and unalterable, and it often blocks and impairs the cultural duality; it distorts the sense of self and alters the sense of belonging, as one needs a special "ticket" to enter. Trumpism, encapsulated in "America First" and "Make America Great Again," enforces the we/they dichotomy that goes against history and against human nature. The more Trump inserts himself as leader, defender, and protector of the vertical America, the more revealing his racial prejudice and xenophobia become, and the more he disfigures Americanism. The existence of the disjointed and antagonistic vertical and horizontal Americas in itself is a disfigurement of Americanism. In making America great again, Trumpism is making America more vertical and Americanism more disfigured.

Received: 3 April 2018 Accepted: 11 September 2018

Published online: 25 September 2018

\section{Notes}

1 Erin Burnett out front, "Swastika-wearing man: this is my country" https://www.cnn. com/videos/us/2018/08/10/ulysses-pennsylvania-sidner-erin-pkg-vpx.cnn

2 Mimi Yang's "Crossing between the Great Wall of China and the "Great" Wall of Trump" was published by Palgrave Communication in November 2017. This was the author's first writing on Trumpism.

3 Why Did the Puritans Really Leave England for the New World?

4 "City upon a hill", has its origin in Matthew 5:14, "You are the light of the world. A city that is set on a hill cannot be hidden." The phrase was rephrased by Puritan John Winthrop in his sermon in 1630 "A Model of Christian City" to his first group of Massachusetts Bay colonists. It is now a political lexicon in American English. Winthrop, J (1996) "A Model of Christian Charity." The Journal of John Winthrop, 1630-1649, Harvard University Press. p.1 and note 1. Also see Wikipedia https://en. wikipedia.org/wiki/City_upon_a_Hill

5 Simon Von Oort, "Strangers Revisited: Reading Donald Trump through John Higham.” http://www.baas.ac.uk/usso/strangers-revisited-reading-donald-trumpthrough-john-higham/\#_ftn1 Accessed 17 March 2018

6 Indirect quote from Oort. John Higham, Strangers in the Land: Patterns of American Nativism, 1860-1925, (Rutgers University Press, 2002), p. 303.

7 My secondary quote of the Know-Nothing journal, from Higham, p.4

8 https://www.cnn.com/2018/03/10/politics/steve-bannon-national-front/index.html. Accessed 12 March 2018

9 Ibid

10 https://www.youtube.com/watch?v=loN56tcy5QQ. Accessed 12 March 2018

11 Ibid

12 Huffpost, Business, "Macy’s Discriminated Against Immigrant Employees, U.S. Finds” https://www.huffingtonpost.com/2013/06/27/macys-immigrants_n_3511324. html. Accessed 18 March 2018

13 Throughout the article, all quotations from Martin Luther King's speech "The Other America" were first transcribed from youtube https://www.youtube.com/watch? $\mathrm{v}=\mathrm{m} 3 \mathrm{H} 978 \mathrm{KIR} 20$ and then compared with the excerpts from The Radical King, published by Beacon Press, 2015,. http://www.beacon.org/The-Radical-King-P1049. aspx. The transcriptions are mine

14 This quote is based on both the youbue (Ibid.) and excerpts from The Radical King, published by Beacon Press, 2015. http://www.beacon.org/The-Radical-King-P1049. aspx

15 Ibid

16 Ibid

17 Ibid
18 Ibid

19 http://www.washingtonpost.com/wp-dyn/articles/A19751-2004Jul27.html

20 Ibid

21 Ibid

22 Mimi Yang, The Tricultural Personality

23 My narrative of Mr. Khizr Khan's personal story is based on Moni Basu's CNN article. https://www.cnn.com/2018/07/20/us/khizr-khan-the-making-of-an-activist/ index.html.

\section{References}

Atwater DF (2007) Senator Barack Obama; the rhetoric of hope and the American dream. J Black Stud 38(2):121-129

Basu M (2018) He came to this country with $\$ 200$ and hope. How Khizr Khan's American dream led him into a battle with Trump. https://www.cnn.com/ 2018/07/20/us/khizr-khan-the-making-of-an-activist/index.html. Accessed 28 July 2018

Dinnerstein L, Reimers DM (2004) M. John Higham and Immigration History. J Am Ethn Hist 24(1):3-25

Higham J ([1954]2002) Strangers in the land: patterns of American nativism, 1860-1925. Rutgers University Press: New Brunswick, NJ

Meacham J (2018) The soul of America: the battle for our better angels. Random House, New York, NY

Meagher T (2012) Revisiting John Higham's "Strangers in the Land": Comment. Jouranl Gilde Age Progress Era 11(2):282-290

Merelman R (1994) Racial conflict and cultural politics in the United States. J Polit 56(1):1-20

Obama B (2006) Audacity of hope: thoughts on reclaiming American Dream. Crown Publishers, New York, NY

Obama B (2004) Out of many, one. http://www.washingtonpost.com/wp-dyn/ articles/A19751-2004Jul27.html. Accessed 15 Mar 2018

Rodríguez V (2009) America beyond Black and White: how immigrants and fusions are helping US overcome the racial divide. Cent J 21(1):264-268

Winthrop J (1996) A model of Christian charity. The journal of John Winthrop, 1630-1649. Harvard University Press: Cambridge, MA

Yang M (2017) Crossing between the Great Wall of China and the "Great" Wall of Trump Palgrave Commun 25:1-6

Yang M (2014) The tricultural personality (Chinese, Hispanic, English): a paradigm for connecting culture differences. Edwin Mellen, New York, NY

\section{Data availability}

Data sharing is not applicable to this paper as no datasets were analysed or generated.

\section{Additional information}

Competing interests: The author declares no competing interests.

Reprints and permission information is available online at http://www.nature.com/ reprints

Publisher's note: Springer Nature remains neutral with regard to jurisdictional claims in published maps and institutional affiliations.

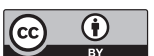

Open Access This article is licensed under a Creative Commons Attribution 4.0 International License, which permits use, sharing, adaptation, distribution and reproduction in any medium or format, as long as you give appropriate credit to the original author(s) and the source, provide a link to the Creative Commons license, and indicate if changes were made. The images or other third party material in this article are included in the article's Creative Commons license, unless indicated otherwise in a credit line to the material. If material is not included in the article's Creative Commons license and your intended use is not permitted by statutory regulation or exceeds the permitted use, you will need to obtain permission directly from the copyright holder. To view a copy of this license, visit http://creativecommons.org/ licenses/by/4.0/.

(C) The Author(s) 2018 